International Journal of Social Science And Human Research

ISSN(print): 2644-0679, ISSN(online): 2644-0695

Volume 04 Issue 11 November 2021

DOI: 10.47191/ijsshr/v4-i11-28, Impact factor-5.586

Page No: $3266-3268$

\title{
The Role And Importance of the Formation of the Middle Class in the Development of Society
}

\author{
Bobir R. Berdiev \\ Doctor of Philosophy in Sociology (PhD), Researcher of the National University of Uzbekistan Tashkent, Uzbekistan
}

\begin{abstract}
In the article, the author examines the criteria for determining the social middle class and theoretical and methodological approaches to the study of this topic, and also conducts a comparative analysis of approaches to determining the social middle class. The main criteria in general and specific approaches to the study of the problem are investigated.
\end{abstract}

KEYWORDS: sociology, social class, middle class, stratification theory, stratification criteria.

\section{INTRODUCTION}

The issue of social stratification, that is, social class and their role in the life of society is one of the fundamental problems of sociology. This area requires a comprehensive study of the complex processes of social stratification, their patterns and mechanisms on a scientific basis. This allows us to anticipate situations that could threaten the life of society and its stability.

The widening gap between social classes is characteristic not only of societies in the process of transformation. Modern processes of globalization, unprecedented rates of socio-economic changes complicate the social stability of a certain part of the population, even in post-industrial societies. However, in such societies, conflicts between social classes do not develop into uncompromising conflicts. This is primarily due to the "middle class", which is the basis of society and plays an important role in ensuring socio-economic stability.

Sociologists assess this segment of the population as a force that shapes society's need for modernization, denies all forms of political tension, and guarantees stability. This requires 50-60\% of society to be "middle class" - in a country striving for civil society, the government should strive for this.

\section{THE MAIN FINDINGS AND RESULTS}

Scientific theories about the stratification of society, formed in the twentieth century, sought to study society from the point of view of stratification in all periods of human history. In relation to society, the concept of "social class", especially the "middle class" ("In any state there are three class: one rich, the other poor). Aristotle, who was the first to use the third, argued that the more such a layer, the more stable that society would be [1]. In the social views of the Eastern thinkers Abu Nasr al-Farabi [2], Abu Rayhan al-Biruni [3], Nizam al-Mulk [4], and others, the question of class and their place in society also occupies a significant place.

The issue of social stratification is widely studied in Western sociology (in particular, representatives of classical sociology: M. Weber [5], E. Goblo [6], E. Giddens [7], P. Sorokin [8] and others).

In a general sense, the concept of "social class" in sociology refers to the vertical section of individuals or groups in terms of income, access to education, possession and influence of power, and professional status. The modern understanding of social class is more complex - multi-layered (polychotomic), multidimensional and fragmentary: censuses, quotas, certifications, class description, career level, privileges, etc.

There are also different views on social stratification and the resulting social inequality. On the one hand, inequality is a historical necessity that must never be abandoned. On the other hand, it is a problem that can be solved and it must be tried to find a solution. The first approach was put forward by Western scholars, the second approach by former Soviet scholars [9].

While the Italian economist and sociologist V. Pareto believes that "social classes exist in any society when the shape changes, [10] the well-known Russian-American sociologist P. Sorokin said, "A society without clsses and absolutely equal members is a myth. non-existent" and this is due to the internal biopsychic differentiation of humans; the environment (natural and social) makes individuals objectively unequal; explains factors such as the division of society into managers and governors, which is a product of individuals' desire to live as a team [11].

The concept of "middle class" entered sociology in the twenties of the twentieth century and is essentially associated with criticism of the Marxist concept. From the point of view of the theory of social stratification, the concept of "middle class" is 


\section{The Role And Importance of the Formation of the Middle Class in the Development of Society}

abstract and relative. Because it does not consist of a particular social stratum, class or group. This class consists of different social groups, class with different worldviews, cultural levels, political inclinations and aspirations. This can also be seen in the fact that the rates for this concept differ.

The classical German sociologist M. Weber describes this layer as "a layer with all kinds of private property and competitive potential in the labor market, which can maintain its strong position through these sources" [12].

The French sociologist F. Simian sees the "middle class" as "people with a stable income for themselves and their families, moderate land ownership, and a strong position among the upper classes and the working class" [13].

According to the well-known Russian sociologist L.A. Belyaev, "the middle class is a real social group on the path of modernization. The middle class is a social product with material resources, cultural capital, characteristics and features of social status" [14].

"The middle class is those who have their own property, ie housing, personal vehicles, who are able to provide for themselves and their families in a decent way, who have sufficient financial resources to meet their basic needs (education, recreation, access to quality health care). and most importantly, citizens who are able to provide this opportunity at the expense of their salaries and incomes and actively participate in the socio-political life of society [15].

It should be noted that the criteria for describing the scientific layout of this layer are different. Foreign researchers base their assessment of belonging to the "middle class" mainly on the following criteria: social status (position, profession and, of course, level of education); income and consumption capacity; self-assessment (self-identification); worldview, value system, life principles.

In this case, the more objective ("income level") and subjective ("self-assessment") criteria are universal. However, such an evaluation criterion poses certain difficulties: for example, the application of criteria that are appropriate for Western countries may not be effective for Eastern countries. The criterion of "self-assessment of one's own status" also makes it difficult to achieve objective results against the background of social status. For example, in 2019, the site "Kun.uz" in a public opinion poll conducted in our country, $67 \%$ of respondents said that they consider themselves middle class.

It is the middle class that makes up the bulk of material wealth, does not depend on the state for subsistence, and is the backbone of society. The formation of such a layer also prevents a sharp stratification of society. It is constantly changing and enriching its content at the expense of newcomers. In an open society, some talented and aspiring middle-class people will be able to rise to a higher social status and move to a higher class. At the same time, the representatives of this stratum are characterized by impoverishment, proletarianization and even lumpenization.

As early as the first half of the last century, A. Toynbee, in his comments on modern civilization, came to the conclusion that it was a middle- class civilization [16]. In our view, this definition of A. Toynbee is more appropriate than today's postindustrial societies.

In a postindustrial society, the weight of the middle class is relatively predominant. The bulk of the working class earns enough to meet the needs of their family, while most people also earn extra income through stocks and other securities. The number of well-paid skilled workers, managers, engineers and technicians will increase sharply.

The numerical superiority of the middle class, the improved living conditions of this stratum, provides general stability in a postindustrial society. Because in such conditions the socio-class ground of the ideology that encourages class struggle becomes very narrow. In other words, the "middle class" also serves as a kind of social consensus in society, the growth of which is interpreted as a condition of social stability.

Particular attention is paid to the specificity of stratification processes in our country, new laws and trends, the optimization of relations between different class. "It is no secret that in the regions, especially in rural areas, the majority of the population does not have a sufficient source of income. As in any country, we have low-income groups. According to various estimates, they make up about 12-15 percent. It's not about small numbers, it's about 4-5 million people" [17].

World experience shows that the development of small and medium-sized businesses plays an important role in the formation of the "middle class". During the transition to a market economy in Uzbekistan, as an effective way to form such a layer, priority was given to the development of small and medium-sized businesses, thereby forming a middle class.

Especially in recent years, targeted state programs have been developed to form the middle class and improve the living standards of the population. Extensive measures are being taken to provide social protection, support entrepreneurship, increase the role, place and activity of citizens in building civil society. In this process, the study of public opinion plays an important role.

According to the Center for Economic Research, the share of the middle class in Uzbekistan is 28-30\%, about 45-48\% of the population are "middle class reserves", which under certain conditions can be included in the middle class or low-income. According to experts, by $2030,60 \%$ of the population of Uzbekistan will be middle class [18].

One of the biggest changes in our country in recent years is the growth in real incomes of the employed population (real income is income calculated taking into account inflation; it serves as a reference for calculating income in different years). According to the Central Bank of the Republic of Uzbekistan, for 9 months of 2021, household income increased by $10.4 \%$ in real terms [19]. 


\section{The Role And Importance of the Formation of the Middle Class in the Development of Society}

Today the average worker earns 3-4 times more than in previous years, and the incomes of managers and those involved in mental work have grown even more. Based on the above, we can say that in Uzbekistan, small business and private entrepreneurship play a key role in the formation of the "middle class".

\section{CONCLUSION}

In short, in order to further accelerate the formation of the "middle class", it is necessary to provide more freedom and privileges to entrepreneurship, put an end to the monopolization of economic sectors, improve the quality of education, the widespread introduction of innovative ideas, constantly increase the creative potential of the population.

Quantitative and qualitative strengthening of the "middle class" in society, along with ensuring social stability: strengthening the civic position of the population; an increase in the number of taxpayers; increase in investment flows, including domestic investment; serves the development and perpetuation of spiritual values.

\section{REFERENCES}

1) Aristotle. Politics // Aristotle. Cit: In 4 volumes. M: 1983. T. 4.

2) Farabi A.N. Fozil is a city of people. Tashkent: "People's heritage", 1993; Farabi A.N. Brochures. Tashkent: "Fan", 1995.

3) Abu Rayhan Beruni. Selected works. Volume II.

4) Electronic source:https://ziyouz.uz/kutubxona/yangi-kitoblar/nizomulmulk-siyosatnoma-siyar-ul-muluk

5) Weber M. Basic concepts of stratification // Kravchenko A.I. Max Weber's Sociology: Labor and Economics. M., 1997; Weber M. Estate and classes / Transl. with him. // Bulletin of Moscow State University. Series 18. Sociology and Political Science. 2003. No. 4.

6) Goblo E. Class and profession // General sociology. Reader / Comp. A.G. Zdravomyslov, N.I. Lapin / Society. ed. N.I. Lapin. Moscow: 2006.

7) Giddens E., Sutton F. Basic concepts in sociology. Moscow: Ed. House of the Higher School of Economics, 2018. 336 p. - ISBN 978-5-7598-1525-9; Giddens E. Stratification and class structure // Sociological research. 1992. No. 9. -pp. 112 $-123$.

8) Man. Civilization. Society / Pitirim Sorokin; [Common. ed., comp. and foreword, p. 5-24, A. Yu. Sogomonova]. Moscow: Politizdat, 1992. - 542, [1] p. - (Thinkers of the XX century. Editorial board: T. I. Oizerman (previous) and others). ISBN 5-250-01297-3; Social mobility / Pitirim Sorokin; [per. from English M. V. Sokolova]. Moscow: Academia: LVS, 2005.- XX, 588 p. ISBN 5-87444-6. Goblo E. Class and profession // General sociology. Reader / Comp. A.G. Zdravomyslov, N.I. Lapin / Society. ed. N.I. Lapin. M.,

9) Ardelyanova Ya.A. Corruption, trust and inequality in modern societies. Moscow University Bulletin. Ser. 18. Sociology and Political Science. 2014. No. 2. - p. 212.

10) Pareto V. Traite de sociologio rale. P., 1919. Vol. 1. -p. 613.

11) Sorokin P.A. Human. Civilization. Society. Moscow: 1992. -p. 304.

12) Weber M. Basic concepts of stratification // Kravchenko A.I. Max Weber's Sociology: Labor and Economics. Moscow: 1997. -p. 175.

13) Bell, D. The Coming Post-Industrial Society. Experience of social forecasting / D. Bell. Moscow: Academia, 1999. -p. 183.

14) Belyaev L.A. And again about the middle class / Sociological research. 2007. No: 5. -p. 17.

15) A.J. Kholbekov, T.B. Matiboev Social justice and democracy: on the path of sustainable development. New Century Generation, 2004. -p. 13.

16) Toynbee A. Comprehension of history / A. Toynbee. Moscow: INFRA-M, 1991. -p. 360.

17) Address of the President of the Republic of Uzbekistan Sh. Mirziyoyev to the Oliy Majlis. http://uza.uz/oz/politics/zbekiston-respublikasi-prezidenti-shavkat-mirziyeevning-oliy-25-01-2020

18) https://xs.uz/ru/post/obsudim.

19) https://uza.uz/ru/posts/joriy-yilning-otgan-davrida-aholi-daromadlari-104-foizga-oshdi_313053?q=\%2Fposts\%2Fjoriyyilning-otgan-davrida-aholi-daromadlari-104-foizga-oshdi_313053 